\title{
Prosedur Penggunaan Aplikasi Sistem Informasi Manajemen Daerah Keuangan Berbasis Akrual pada Dinas Kebudayaan Kabupaten Gianyar
}

\section{Anak Agung Putu Gede Bagus Arie Susandya, I Gusti Ayu Medy Kayana Putri}

\author{
Program Studi Akuntansi \\ Fakultas Ekonomi dan Bisnis, Universitas Mahasaraswati Denpasar, Jl. Kamboja No.11A, Bali, Indonesia \\ Email: ariesusandya@unmas.ac.id
}

\begin{abstract}
Abstrak
Perkembangan teknologi informasi komunikasi yang semakin pesat telah mempengaruhi sistem pengolahan data dan sistem informasi pada entitas yang melakukan pelaporan data keuangan. Untuk dapat melakukan pengolahan data keuangan secara efektif dan efisien maka dibutuhkan suatu sistem informasi terintegrasi yang dapat diandalkan, cepat dan akurat sehingga suatu sistem dapat terintegrasi secara menyeluruh dan mampu memberikan informasi yang handal dan relevan. Program aplikasi komputer SIMDA keuangan adalah suatu program aplikasi yang ditujukan untuk membantu pemerintah daerah dalam pengelolaan keuangan daerahnya. Perencanaan dan laporan pelaksanaan kegiatan pada pemerintah daerah menggunakan aplikasi sistem informasi. Penelitian ini bertujuan untuk menganalisisa kemampuan pegawai dalam penggunaan aplikasi Sistem Informasi Manajemen Daerah (SIMDA) Keuangan berbasis akrual pada Dinas Kebudayaan Kabupaten Gianyar. Metode pelaksanaan yang digunakan adalah pemahaman, pendampingan dan pelatihan kepada pegawai yang terlibat dalam penggunaan aplikasi SIMDA Keuangan dengan total 3 orang. Hasil kegiatan menunjukkan bahwa prosedur penggunaan aplikasi SIMDA Keuangan berbasis akrual dapat meningkatan kemampuan pegawai dalam memahami penggunaan aplikasi SIMDA Keuangan berbasis akrual.
\end{abstract}

Kata Kunci: Internet, SIMDA, Pemerintah Kabupaten Gianyar, Akrual, Sistem Informasi Akuntansi

\section{Pendahuluan}

Widiastuti (2015) menyatakan bahwa sistem informasi akuntansi berbantuan computer merupakan proses pengelolaan data/transaksi, yang dimulai dari mulai penginputan data, penyimpanan dan pemrosesan data, sehingga dapat menghasilkan suatu laporan keuangan yang dibutuhkan oleh pihak yang berkepentingan dengan menggunakan system komperisasi. Tujuan dari pelaporan keuangan adalah menyediakan informasi mengenai kondisi keuangan suatu entitas dan perubahan yang terjadi dan menyediakan informasi secara keseluruhan yang berguna dalam mengevaluasi kinerja entitas menyangkut biaya jasa, efisiensi, dan pencapaian tujuan (Nugraha \& Astuti, 2013). Program aplikasi komputer SIMDA keuangan adalah suatu program aplikasi yang ditujukan untuk membantu pemerintah daerah dalam pengelolaan keuangan daerahnya. Maka dari itu pemerintah Gianyar menerapkan Sistem Informasi Manajemen Daerah Keuangan (SIMDA Keuangan) berbasis akrual untuk pengelolaan keuangan daerah secara terintegrasi yang nantinya akan digunakan untuk pengambilan keputusan dalam berbagai hal di sektor pemerintahan. Alfian (2014) menemukan bahwa implementasi SIMDA memiliki pengaruh positif terhadap kualitas laporan keuangan. Pentingnya peningkatan kualitas SIMDA karena dengan membaiknya penerapan SIMDA maka dapat meningkatkan kualitas laporan keuangan yang dihasilkan. Salah satu permasalahan yang terungkap dari hasil observasi di Dinas Kebudayaan Kabupaten Gianyar khususnya di bagian keuangan adalah dimana kurangnya kemampuan pegawai dalam penerapan aplikasi Sistem Informasi Manajemen Daerah Keuangan (SIMDA Keuangan) sebagai sistem informasi pengelola keuangan daerah. Program aplikasi SIMDA Keuangan yang digunakan pada Dinas Kebudayaan adalah program aplikasi SIMDA Keuangan versi 2.7 berbasis akrual yang terdiri dari tiga bagian yaitu: Penganggaran, Penatausahaan, akuntansi dan pelaporan.

Kondisi faktual menunjukkan bahwa selama ini pegawai di bagian keuangan ketika menggunakan aplikasi SIMDA Keuangan berbasis akrual untuk melaporkan kondisi keuangan 
mengalami kesulitan karena kurangnya pegawai dalam mengakses laporan keuangan ke dalam aplikasi Sistem Informasi Manajemen Daerah Keuangan (SIMDA Keuangan). Dalam rangka dapat memberikan informasi yang baik yang mengambarkan kondisi riil instansi, maka untuk mengatasi permasalah ini perlu diberikan pemahaman, pedampingan dan pelatihan kepada pegawai dalam penggunaan aplikasi Sistem Informasi Manajemen Daerah Keuangan (SIMDA Keuangan). Azzindani et al. (2019) berpendapat bahwa sumber daya manusia memiliki peranan penting dalam tercapainya penerapan SIMDA yang efektif dan efisien. Menurut Maksum et al. (2017), keinovatifan personal berpengaruh positif terhadap kegunaan persepsian, ini berarti bahwa semakin tinggi perilaku inovatif pengelola keuangan maka semakin mampu seseorang untuk menggunakan cara alternatif dan lebih memahami kegunaan SIMDA untuk membantu pekerjaannya. Kreatifitas dari pegawai juga diperlukan dalam hal efisiensi penerapan SIMDA Keuangan.

Solusi yang digunakan dalam memecahkan permasalahan yang dialami oleh instansi di Dinas Kebudayaan Kabupaten Gianyar khususnya pada bidang keuangan mengenai kurangnya pegawai yang memahami cara mengoperasikan aplikasi Sistem Informasi Manajemen Daerah Keuangan (SIMDA Keuangan) berbasis akrual dengan cara:

1) Memberikan pemahaman mengenai SIMDA Keuangan dan tata cara mengoperasikan Sistem Informasi Manajemen Daerah Keuangan (SIMDA Keuangan) berbasis akrual kepada pegawai khususnya pegawai di bagian keuangan pada Dinas Kebudayaan Kabupaten Gianyar.

2) Melaksanakan pendampingan penggunaan aplikasi Sistem Informasi Manajemen Daerah Keuangan (SIMDA Keuangan) berbasis akrual kepada pegawai khususnya pegawai di bagian keuangan pada Dinas Kebudayaan Kabupaten Gianyar.

3) Memberikan pelatihan tata cara penggunaan aplikasi Sistem Informasi Manajemen Daerah Keuangan (SIMDA Keuangan) berbasis akrual yang terdiri dari penganggaran, penatausahaan, akuntansi dan pelaporan kepada pegawai pada bagian keuangan pada Dinas Kebudayaan Kabupaten Gianyar.

\subsection{Tujuan Kegiatan}

Tujuan kegiatan ini adalah untuk melatih pegawai pada Dinas Kebudayaa Kabupaten Gianyar menggunakan SIMDA Keuangan. Dengan terimplentasinya SIMDA Keuangan ini maka diharapkan pegawai bidang keuangan dapat membuat laporan keuangan maupun input transaksi dengan lebih transparan. Apalagi dengan adanya pandemi Covid-19 untuk tetap saling menjaga jarak tetapi aktivitas input data keuangan tetap berjalan maksimal.

\subsection{Manfaat Kegiatan}

Manfaat yang diharapkan dari pelatihan ini adalah pegawai dapat bekerja secara efektif dan efisien baik dikantor maupun di rumah. Penginputan data transaksi keuangan bisa terinventarisasi dalam bentuk digital.

\subsection{Luaran Pengabdian Kepada Masyarakat}

Target Luaran dalam kegiatan pengabdian kepada masyarakat ini, yaitu:

a. Pegawai Dinas Kebudayaan Kabupaten Gianyar dapat memanfaatkan SIMDA Keuangan dalam pengelolaan keuangan.

b. Terjadi peningkatan kinerja pegawai bidang keuangan pada Dinas Kebudayaan Kabupaten Gianyar.

\section{Realisasi Kegiatan}

\subsection{Bentuk Kegiatan \& Jadwal, Serta Tempat Kegiatan \\ a. Metode Pelaksanaan Kegiatan}

Pengabdian masyarakat dilakukan dengan cara memberikan pemahaman, pendampingan dan pelatihan kepada pegawai khususnya di bidang keuangan. Metode yang digunakan adalah metode pemahaman, pendampingan dan pelatihan. Metode pemahaman tentang penggunaan aplikasi Sistem Informasi Manajemen Daerah Keuangan (SIMDA Keuangan) berbasis akrual dilaksanakan selama 1 hari dengan memberikan pemahaman mengenai cara menginstal aplikasi SIMDA 
Keuangan, setting configurasi, dan setting aplikasi. Metode pendampingan dan pelatihan terhadap pegawai tentang penggunaan aplikasi Sistem Informasi Manajemen Daerah (SIMDA) berbasis akrual dilaksanakan selama 4 hari.

b. Waktu Efektif Pelaksanaan Kegiatan

Kegiatan Pelaksanaan Pengabdian Kepada Masyarakat ini akan dilaksanakan pada Tanggal 2 Maret 2020 sampai dengan 6 Maret 2020 dengan rincian sebagai berikut:

Tabel 1. Jadwal Pelaksanaan

\begin{tabular}{|c|l|c|c|c|c|c|}
\hline \multirow{2}{*}{ NO } & \multicolumn{1}{|c|}{ Kegiatan } & \multicolumn{3}{|c|}{ Jadwal Pelaksanaan Tanggal : } & $\mathbf{5}$ & $\mathbf{6}$ \\
\cline { 3 - 6 } & & $\mathbf{2}$ & $\mathbf{3}$ & $\mathbf{4}$ & $\mathbf{5}$ & \\
\hline 1 & Pemahaman materi & & & & \\
\hline
\end{tabular}

Pelaksanaan Pengabdian Masyarakat sesuai dengan jam kerja pegawai pada Dinas Kebudayaan Kabupaten Gianyar sebanyak 5 hari kerja dalam seminggu.

- Senin-Kamis : Pukul 07.30-15.00 Wita.

- Jumat : Pukul 06.30-14.00 Wita.

\section{c. Tempat Kegiatan}

Pelaksanaan Pengabdian Masyarakat bertempat di Dinas Kebudayaan Kabupaten Gianyar yang terletak di Jalan Kebo Iwa, Gianyar. Pengabdian Masyarakat pada Dinas Kebudayaan Kabupaten Gianyar dilaksanakan pada bagian Keuangan dimana Sub Bagian Keuangan mempunyai tugas melaksanakan pengelolaan keuangan, barang milik daerah dan milik negara, melaporkan laporan keuangan pada pimpinan di atasnya, dan layanan pengadaan barang/jasa di Dinas.

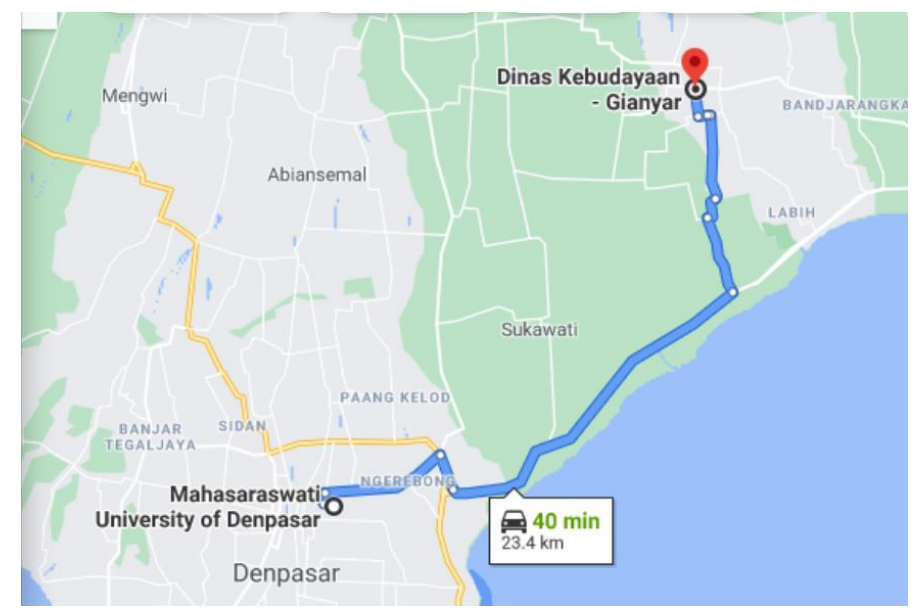

Gambar 1. Maps Lokasi

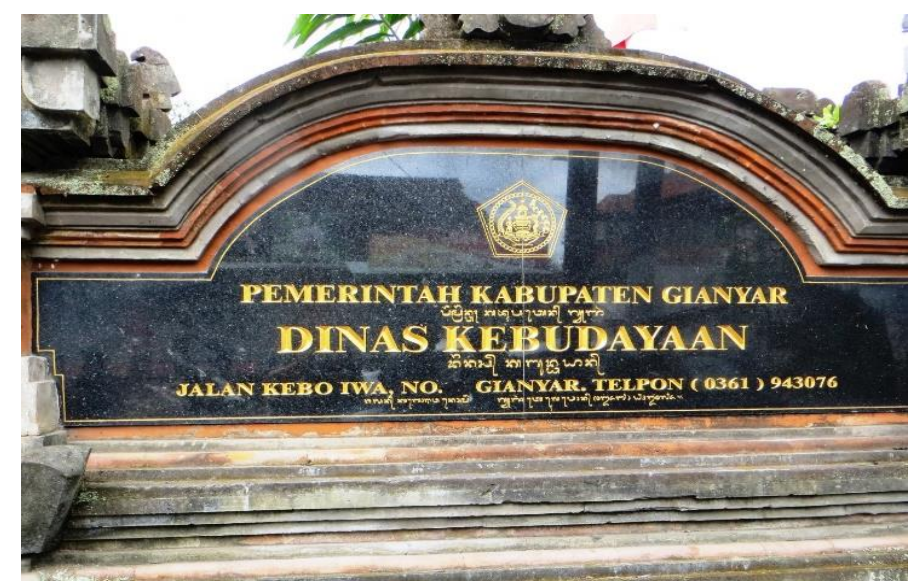




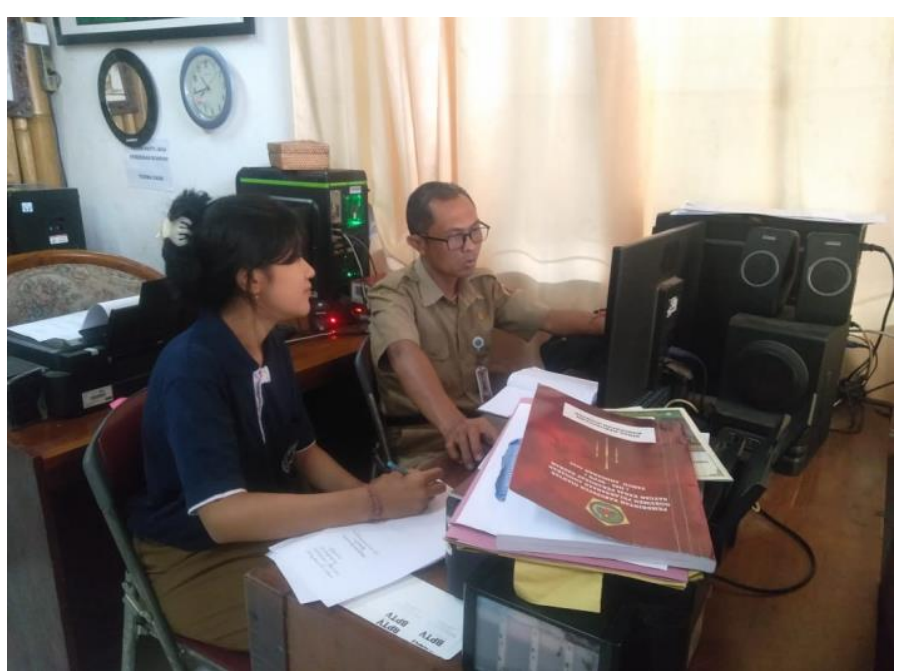

Gambar 2. Lokasi Pengabdian

\subsection{Materi}

Pelaksanaan SIMDA Keuangan versi 2.7 terdiri dari 3 bagian yaitu:

1. Penganggaran. Metode yang digunakan dalam pelatihaan penganggaran adalah pengisian data umum dan pengisian parameter.

2. Penatausahaan. Metode yang digunakan dalam pelatihan penatausahaan adalah pengisian parameter peraturan daerah, pengisian parameter penandatangan dokumen, pengisian parameter rekening, pengisian parameter rekening akrual, rekening potongan SPM, dan pengisian parameter bank.

3. Akuntansi dan pelaporan. Metode yang digunakan dalam pelatihan akuntansi dan pelaporan adalah memasukkan saldo neraca awal, jurnal balik, posting transaksi tahun berjalan, pencatatan koreksi, rekonsiliasi saldo buku kas daerah, reklasifikasi akhir tahun,dan proses tutup tahun.

Output SIMDA Keuangan berbasis akrual dilengkapi dengan buku pedoman yang terdiri dari:

1. Buku Manual Sistem dan Prosedur Penganggaran.

2. Buku Manual Sistem dan Prosedur Penatausahaan.

3. Buku Manual Sistem dan Prosedur Akuntansi dan Pelaporan.

\subsection{Masyarakat Sasaran}

Seluruh pegawai negeri sipil maupun pegawai kontrak yang bernaung dibawah bidang keuangan pada Dinas Kebudayaan Kabupaten Gianyar.

\section{Tinjauan Hasil Yang Dicapai}

Hasil yang diperoleh dalam kegiatan pengabdian masyarakat di Dinas Kebudayaan Kabupaten Gianyar yang berjudul prosedur penggunaan aplikasi SIMDA Keuangan berbasis akrual pada Dinas Kebudayaan Kabupaten Gianyar telah berhasil ditingkatkan melalui pemahaman, pendampingan, dan pelatihan. Secara keseluruhan kegiatan yang telah dilakukan berjalan dengan baik dan lancar. Melalui program peningkatan kemampuan pegawai dalam menggunakan aplikasi SIMDA Keuangan berbasis akrual akan memberikan pemahaman dari pihak perusahaan dan pegawai dimana dari program kerja tersebut berguna untuk perusahaan dan pegawai akan pentingnya penggunaan aplikasi SIMDA Keuangan berbasis akrual dalam mengetahui kondisi yang terjadi di Satuan Kerja Perangkat Daerah (SKPD) dan sebagai media melaporkan laporan keuangan. Hasil ini sejalan dengan Hardjanto (2019) serta Wibisono (2017) yang menemukan bahwa pegawai memegang peranan penting dalam suksesnya penerapan SIMDA Keuangan di Organisasi Perangkat Daerah. 
Kegiatan pertama yang dilaksanakan dalam pengabdian masyarakat di Dinas Kebudayaan Kabupaten Gianyar memberikan pemahaman kepada pegawai mengenai tata cara pengoperasian aplikasi SIMDA Keuangan berbasis akrual. Pemahaman mengenai pegoperasian aplikasi SIMDA Keuangan berbasis akrual dilaksanakan pada pegawai di bidang keuangan yang diikuti oleh 3 orang pegawai, hasil yang diperoleh dalam pengabdian masyarakat ini adalah pegawai mampu menginstal aplikasi SIMDA Keuangan berbasis akrual dengan baik.

Kegiatan pengabdian masyarakat yang kedua yaitu pendampingan dan pelatihan kepada pegawai dalam menginput data pada aplikasi Sistem Informasi Manajemen Daerah Keuangan (SIMDA Keuangan) berbasis akrual. Pendampingan dan pelatihan mengenai tata cara menginput dipedomi dengan buku panduan dan diikuti oleh 3 orang pegawai dalam bidang keuangan. Hasil yang diperoleh dalam pendampingan penggunaan aplikasi SIMDA Keuangan berbasis akrual adalah dengan berhasilnya para pegawai menginput data ke dalam aplikasi SIMDA Keuangan berbasis akrual sesuai arahan buku pedoman.

\section{Daftar Pustaka}

Alfian, M. (2014). Analisis Faktor Pendukung Implemetasi SIMDA dan Pengaruhnya Terhadap Kualitas Laporan Keuangan Pada SKPD ( Penelitian pada SKPD di Lingkungan Pemerintah Daerah Kabupaten Kulon Progo ). 3rd Economics \& Business Research Festifval.

Azzindani, R., Pituringsih, E., \& Irwan, M. (2019). Pengaruh Implementasi SIMDA, Kinerja Aparatur Pemerintah Daerah dan Penerapan SAP Terhadap Kualitas LKPD Lombok Tengah. E-Jurnal Akuntansi. https://doi.org/10.24843/eja.2019.v27.i01.p16

Hardjanto, K. (2019). IMPLEMENTASI SISTEM INFORMASI MANAJEMEN DAERAH (SIMDA) KEUANGAN BERBASIS AKRUAL PADA DINAS PERTANIAN DAN PANGAN KOTA MAGELANG. JURNAL TEKNIK INFORMATIKA. https://doi.org/10.15408/jti.v12i1.6263

Maksum, U., Baridwan, Z., \& Subekti, I. (2017). The Determinant of Acceptance of SIMDA (Information System of District Management) Implementation on the Government of Batu City. Journal of Accounting and Business Education. https://doi.org/10.26675/jabe.v1i2.8494

Nugraha, H. A., \& Astuti, Y. W. (2013). Analisis Penerapan Sistem Informasi Manajemen Keuangan Daerah ( SIMDA Keuangan ) dalam Pengolahan Data Keuangan Pada Organisasi Pemerintah Daerah ( Studi Kasus Pada Dinas Kesehatan Kabupaten Nganjuk). Jurnal Akuntansi Aktual.

Wibisono, A. F. (2017). Efektifitas Peran BPKP dalam Pembinaan dan Pengawasan Implementasi Sistem Informasi Manajemen Daerah (SIMDA). Jurnal Reviu Akuntansi Dan Keuangan. https://doi.org/10.22219/jrak.v7i1.09

Widiastuti, I. (2015). Sistem Informasi Akuntansi Berbasis Komputer. Bhirawa. Vol. 2. No. 2 Edisi Desember 2015. 